\title{
Moraxella oblonga
}

National Cancer Institute

\section{Source}

National Cancer Institute. Moraxella oblonga. NCI Thesaurus. Code C86529.

A species of aerobic, Gram negative, cocci shaped bacteria assigned to the phylum

Proteobacteria. This species is oxidase and catalase positive, does not reduce nitrate and

is negative for urea and lysine hydrolysis. M. oblong a has been isolated from the oral cavity of a sheep. 